\title{
Narrating technonatures: discourses of biotechnology in a neoliberal era
}

\author{
Myles Carroll ${ }^{1}$ \\ York University, Canada
}

\begin{abstract}
This article considers the role played by discourses of nature in structuring the cultural politics of anti-GMO activism. It argues that such discourses have been successful rhetorical tools for activists because they mobilize widely resonant nature-culture dualisms that separate the natural and human worlds. However, these discourses hold dubious political implications. In valorizing the natural as a source of essential truth, natural purity discourses fail to challenge how naturalizations have been used to legitimize sexist, racist and colonial systems of injustice and oppression. Rather, they revitalize the discursive purchase of appeals to nature as a justification for the status quo, indirectly reinforcing existing power relations. Moreover, these discourses fail to challenge the critical though contingent reality of GMOs' location within the wider framework of neoliberal social relations. Fortunately, appeals to natural purity have not been the only effective strategy for opposing GMOs. Activist campaigns that directly target the political economic implications of GMOs within the context of neoliberalism have also had successes without resorting to appeals to the purity of nature. The successes of these campaigns suggest that while nature-culture dualisms remain politically effective normative groundings, concerns over equity, farmers' rights, and democracy retain potential as ideological terrains in the struggle for social justice.
\end{abstract}

Keywords: biotechnology, political ecology, discourse, cultural studies, nature, social movements, political economy

\section{Résumé}

Cet article considère le rôle joué par les discours de la nature dans la structuration de la politique culturelle de l'activisme anti-OGM. Il fait valoir que de tels discours ont été des outils rhétoriques réussis pour les militants, car ils mobilisent des dualismes de culture de la nature, largement résonnants, qui séparent les mondes naturel et humain. Cependant, ces discours ont des implications politiques douteuses. En valorisant le naturel comme source de vérité essentielle, les discours de la pureté naturelle ne parviennent pas à contester la façon dont les naturalisations ont été utilisées pour légitimer les systèmes sexistes, racistes et coloniaux d'injustice et d'oppression. Plutôt, ils revitalisent l'achat discursif d'appels à la nature comme justification du statu quo, renforçant indirectement les relations de pouvoir existantes. En outre, ces discours ne parviennent pas à contester la réalité critique mais contingente de l'emplacement des OGM dans le cadre plus large des relations sociales néolibérales. Heureusement, les appels à la pureté naturelle n'ont pas été la seule stratégie efficace pour s'opposer aux OGM. Les campagnes militantes qui ciblent directement les implications économiques économiques des OGM dans le contexte du néolibéralisme ont également eu des succès sans recourir à la pureté de la nature. Les succès de ces campagnes suggèrent que, si les dualités de la nature et de la culture restent des bases normatives politiquement efficaces, les préoccupations concernant l'équité, les droits des agriculteurs et la démocratie conservent le potentiel en tant que terrains idéologiques dans la lutte pour la justice sociale.

Mots-clés: biotechnologie, écologie politique, discours, études culturelles, nature, mouvements sociaux, économie politique

1 Myles Carroll, PhD Candidate, Department of Political Science, York University, Toronto, Ontario, Canada. Email: mcarroll "at" yorku.ca. The author wishes to thank two anonymous reviewers for their insights, as well as Dr. James Rowe and Dr. Jessica Dempsey, who supervised the MA thesis that led to this article. 


\section{Resumen}

Este artículo considera el papel que desempeñan los discursos de la naturaleza en la estructuración de la política cultural del activismo anti-OGM. Sostiene que tales discursos han sido herramientas retóricas exitosas para los activistas porque movilizan dualismos de naturaleza-cultura ampliamente resonantes que separan los mundos natural y humano. Sin embargo, estos discursos tienen dudosas implicaciones políticas. Al valorar lo natural como fuente de verdad esencial, los discursos de pureza natural no cuestionan cómo se han utilizado las naturalizaciones para legitimar los sistemas sexistas, racistas y coloniales de injusticia y opresión. Más bien, revitalizan la compra discursiva de apelaciones a la naturaleza como justificación del status quo, reforzando indirectamente las relaciones de poder existentes. Además, estos discursos no desafían la realidad crítica aunque contingente de la ubicación de los OGM dentro del marco más amplio de las relaciones sociales neoliberales. Afortunadamente, los llamamientos a la pureza natural no han sido la única estrategia efectiva para oponerse a los OGM. Las campañas activistas dirigidas directamente a las implicaciones políticas económicas de los OGM en el contexto del neoliberalismo también han tenido éxitos sin recurrir a la pureza de la naturaleza. Los éxitos de estas campañas sugieren que si bien los dualismos naturaleza-cultura siguen siendo fundamentaciones normativas políticamente efectivas, las preocupaciones sobre la equidad, los derechos de los agricultores y la democracia conservan el potencial como terrenos ideológicos en la lucha por la justicia social.

Palabras clave: biotecnología, ecología política, discurso, estudios culturales, naturaleza, movimientos sociales, economía política

\section{Introduction}

As a framework that holds at its core the notion that "politics is inevitably ecological and that ecology is inherently political" (Robbins 2012: 3), political ecology is 'ground zero' for the study of biotechnology in general and GMO agriculture in particular. Indeed, few objects of analysis provide as clear a demonstration of the inherently political character of humanity's relationship with the rest of nature. Struggles over GMO agriculture, as with those over climate change, reinforce how the struggle over political economic relations goes hand-in-hand with the remaking of ecologies. It is therefore pertinent to ask what new insights a political ecological analysis might generate for the study of the politics of GMO agriculture, and in particular of the political struggle over its development.

Much has been made of the relative success of opposition movements against GMO agriculture (Gupta 2015; Herring 2008; Kwiecinski 2009; McCauley 2015; Pigeon and Letourneau 2014; Purdue 2000; Schurman 2004; Schurman and Munro 2010). Indeed, although agricultural biotechnology has made major inroads in the productivity of key volume crops such as corn, cotton, soy and canola, the GMO food economy remains very circumscribed, limited to only two dozen countries (James 2016). Other crops such as wheat, potatoes, tomatoes and rice have failed as successful GMO products (Carroll 2017), and at least 64 countries have instituted bans, moratoria or mandatory labelling policies (CFFS 2013). Global social movements and national governments have further iterated their concerns through the Cartagena Protocol on Biosafety of the Convention on Biological Diversity (CBD) and the CBD's standing moratorium on Genetic Use Restriction Technologies (GURTs), or terminator technology (Carroll 2016). Public and activist pressure has driven retailer-based bans in Britain and elsewhere in Europe and beyond.

It is important to understand these developments in the context of the global neoliberal order. GMO agriculture and biotechnology in general has developed as part of the project of neoliberalism (see also Cooper 2008; Rajan 2012). In order to be profitable, GMO agriculture has relied on nascent intellectual property rights regimes such as the World Trade Organization's TRIPS agreement (Pechlaner 2012). These agreements comprise a legal order that has advanced the constitutionalization, or locking in, of neoliberal social relations globally (Gill 2008). Given GMO agriculture's current imbrication within neoliberal capitalism and its role in contemporary processes of commodification, the relative success of GMO opposition represents an important (though tenuous) victory for progressive struggles against neoliberal hegemony, and an important case study 
for those seeking to understand the wider potentialities of the resistance politics successfully employed in antiGMO activism.

These resistance politics have been advanced through real-world, on-the-ground, material struggles. But they have also relied on particular discourses, narratives or semiotic framings to be intelligible and thus successful. The various ways GMO agriculture has come to be framed semiotically, both within and outside of activist opposition circles, have had a constitutive effect on the direction and results of the movement. While several discourses have provided important framings of GMOs among activists and the public at large, a narrative of GMOs as unnatural, impure, or at odds with the purity of nature has been resonant, and successful in mobilizing resistant energies. However, while much has been written about the relative success of anti-GMO activism (Andree 2007; Schurman and Munro 2009, 2010), and about the role of nature narratives in GMO discourse (Hansen 2006; Haraway 1997; Hughes 2005; Kwiecinski 2009; Levidow 2000; Shaw 2002), the two conversations appear to be relatively segregated. Only Schurman and Munro (2010, 2009), Schurman (2004), Heller (2013) and Fitting (2006, 2011) have examined the use of nature narratives in the context of activist struggles against GMO agriculture, and these studies neither located these narratives within their wider cultural context nor critically examined their political implications. In contrast, this article seeks to explain not only why these narratives were effective in mobilizing opposition but also why they have contradictory political consequences that need to be carefully considered when assessing the value of such narratives to activist campaigns going forward.

I argue that natural purity discourses have been central to the success of GMO activism in the global North partly because of how they have mobilized widely resonant nature-culture dualisms that separate the natural world from the human world. However, these dualisms, though not inherently pernicious, have long been used to justify gendered, racial, class and colonial patterns of oppression and domination, providing 'nature' as a justification for unequal power relations. Moreover, appeals to natural purity alone obscure the malign political economic impacts of GMOs under neoliberalism, where they have represented a further advance of the commodification of nature, empowering large biotech and seed corporations at the expense of farmers. In this way my argument accords with the insights of Haraway (1997), Hansen (2006) and others, who have provided instructive critiques of the problems with nature narratives in anti-GMO discourse, as well as with a wider conversation within political ecology about the relationship between society and nature (see Braun 2009; Castree 2005). The argument taken here thus follows a strong tradition in political ecology (see Smith 1991) of seeing nature as socially constructed or "produced" as a product both of our physical engagement with the world around us and of discourse. This perspective thus explicitly rejects the very idea of "nature" and "society" or "culture" existing as ontologically distinct entities, instead referring to these assemblages as "nature-cultures" or "social-natures" (Braun 2009; Castree 2005; Ekers and Loftus 2013; Swyngedouw 1999).

However, pace Haraway, I argue that natural purity discourses are not the only way to mount successful opposition to GMOs. Activist campaigns that directly target the political economic, neocolonial, and classbased implications of GMOs within the particular context of neoliberalism have also had successes without resorting to appeals to the purity of nature. In this way, they have embodied Gramsci's (1992) notion of good sense, or a critical awareness of the underlying structural basis for existing conditions, rather than common sense, or insufficiently critical and unreflective assumptions that perpetuate and reinforce an existing hegemonic configuration, with which we might characterize the natural purity wing of the anti-GMO movement ${ }^{2}$ (Simon 1982). The successes of these campaigns suggest that while nature-culture dualisms remain politically effective

\footnotetext{
${ }^{2}$ I understand the anti-GMO movement as the cluster of civil society organizations, organized partisan political forces and organic intellectuals from both academia and activist circles who share a common critique in the expansion of GMO agriculture, at under its current configuration within capitalist or neoliberal political economic relations. It is important to note that much heterogeneity exists within the purity wing of the anti-GMO movement and some groups and actors cohere better with Gramsci's notion of common sense than others. My aim is not to divide the anti-GMO movement along a good sense-common sense dichotomy but rather to see these as different activist tendencies that are manifest to varying degrees across a spectrum. In practice, many groups may incorporate both good sense and common sense elements in their analysis and activities. Moreover, the claim is not that common sense is inherently bad and good sense inherently good. Common sense tropes and rhetoric can play a (limited) role in movements driven by overarching structural narratives in ways that appeal more broadly to publics (and thus bring more efficacy) than purely "good sense" approaches.
} 
normative groundings, concerns over equity, farmers' rights, accountability and democracy retain potential as terrains of ideological struggle.

Nonetheless, we must be careful to avoid eschewing the strategic political value of common sense framings altogether. Even good sense resistance efforts occur within an overarching context wherein commonsense tropes and narratives remain widely popular. Movements that can strategically coopt the popular intelligibility of common sense framings within an analysis that is still firmly rooted in good sense critique, hold particular promise for those seeking to challenge existing structures of power from a perspective that is immediately resonant. Thus rather than rejecting nature purity discourses entirely, an approach that strategically employs them while remaining conscious of their limitations is best positioned to resonate with publics whilst retaining its roots in a systemic critique of the underlying structures of injustice and oppression. As a spatially variegated and multifarious component of the wider struggle against neoliberalism and the new enclosures, GMO activism can, and must, seize this normative terrain in the struggle for social justice.

While research on anti-GMO activism in Latin America and elsewhere indicates that there are multiple currents in anti-GMO activism, many of which do not rely on the natural purity narratives emphasized here (see, for example, Fitting 2011; Gupta 2015 and Kinchy 2012), a comprehensive analysis of anti-GMO activism around the world is beyond the scope of this article. Consequently, this article will limit itself spatially to developments in North America, Western Europe and Australasia - the "West" - where natural purity discourses have been most pervasive. The article begins with a brief discussion of the semiotic fluidity of nature and the role of natural discourses in Western environmentalism. Next, it examines specifically how natural purity narratives have been mobilized within anti-GMO discourse, demonstrating the political efficacy of resistance efforts that incorporate nature purity discourses within their rhetoric with a number of examples from various sections of civil society. I explore four cases: the British activist group Genetix Snowball; the New Zealand group Mothers Against Genetic Engineering (MAdGE); the Australian state of Tasmania's government's campaign to keep GMOs out of the state; and the anti-GMO discourse of Austria's leading far right political party, the Freedom Party of Austria (FPO). These cases were selected because they exemplify the use of nature purity narratives in GMO activism and demonstrate their use in a range of political contexts, including both social activism and electoral politics. However, they are not meant to be a representative sample of all anti-GMO activism everywhere.

I therefore locate these resistance efforts within wider cultural discourses, analyzing each of them rhetorically to show how they cohere with wider western cultural motifs, thus considering the basis for their normative success. I then critically assess the problematic implications of these natural purity discourses: how they reinforce the validity of nature-culture dualisms whilst obfuscating the contingent reality of GMO agriculture's imbrication to neoliberal capitalism. Finally, the article explores a set of alternative opposition struggles against GMOs that directly call into question their political economic impacts, drawing on two cases: resistance to the commercialization of GMO wheat in Canada, and resistance to terminator technology around the world. These cases were chosen because they represent two of the most successful and well-known instances of activists successfully resisting GMO agriculture's expansion, providing heuristic examples of what an alternative anti-GMO political praxis might look like. While the study of Saskatchewan farmers' opposition to GMO wheat draws heavily on the work of Emily Eaton (2012), the study of Rural Advancement Fund International's (RAFI; now ETC Group) opposition to Genetic Use Restriction Technologies (GURTS), or terminator technology, draws primarily on pamphlets and other publications distributed by the group during the time of the campaign in the late 1990s.

The successes of these two campaigns indicate that anti-GMO opposition does not have to revolve around nature purity discourses to be successful. Overall, the relative success of anti-GMO activism demonstrates how natural purity narratives are rhetorically very powerful. Yet it also demonstrates that though comparatively difficult, deeper critical attacks on neoliberal hegemony are not just possible but necessary. To that end, I build on the analyses of GMO agriculture that have drawn on Antonio Gramsci's notion of hegemony (see Andree 2007; Newell 2009) by considering the way anti-GMO discourses may be read through a Gramscian theoretical lens, drawing on Gramsci's distinction between good sense and common sense to explore the strategic and political implications of natural purity narratives for activists. I emphasize the value of narratives rooted in "good sense" - i.e., those that emanate from a position of critical reflection of the way 
questions of power and control are elided under hegemonic arrangements. These are privileged over commonsense narratives that take for granted the hegemonic status quo. I argue that groups that have framed their opposition to GMO agriculture in terms of its pernicious effects for farmers and communities in the context of neoliberal social relations, point to the realization of a good sense, rather than a common sense, critique of GMO agriculture. The successes of those efforts must inform critical activist struggles against GMO agriculture and beyond in the future.

\section{Discourses of nature}

Though it is hard to assess exactly how discourses of nature have impacted public opinion on GMOs, research suggests that especially in Europe, they have played a major role in generating opposition to the technology. According to the Public Acceptance of Agricultural Biotechnologies project of the Centre for Studies in Environmental Change at Lancaster University, the idea that GMOs are unnatural was a major source of concern in Europe (Marris 2001; Marris et al. 2001). In a more recent study, Mielby et al. found that 72 percent of EU citizens consider GMOs to be "fundamentally unnatural" (2013: 479). Similarly, Shaw's (2002: 281) more detailed survey of public perceptions toward GMOs in the UK found that "across the range of ... participants, there was a 'gut feeling' that the transfer of genes across the species barrier represented the 'crossing of a line' that should not be crossed." While such findings are not universal and are much less pronounced in North America and in parts of the Global South (Hoban 2004), they indicate a widespread public ambivalence or opposition to GMOs based on the belief that they are unnatural. ${ }^{3}$

It is not by accident that discourses of nature have come to play an important role in anti-GMO activist campaigns. Nature is one of the most politically loaded and normatively significant terms in Western discourse (Williams 1983). Haraway (1997) reminds us that nature "has been the key operator in foundational, grounding discourses for a very long time" (p. 102). However, nature is itself a politically indeterminate concept: "It is the ... semantic richness of 'nature', the ability of the word and the concept to accommodate a multitude of contradictory meanings, that makes it a powerful and flexible construct in virtually any public debate or controversy" (Hansen 2006: 813). Consequently, there are multiple narratives that dominate Western orientations to nature (Castree 2005). As Braun (2009) notes, they include conceptions of nature as separate from the human world, and as inherently inseparable from that of human society. While the latter, hybrid or social nature ontology has become widely resonant within critical social science, the former arguing that separating nature and society according to a dualism has been a driving force behind Western environmentalism (Cronon 1995; see also Braun 2004). This dualistic way of thinking that sees nature and society or culture as ontologically distinct (and often opposing) forces has deep roots in Western philosophy. Humanity's separation from the "natural" world is central to both Christian theology and the post-Enlightenment philosophy that grew out of it, most notably evinced by the mind-body dualism of René Descartes (Braun 2009). These deep-rooted cultural understandings of the relationship between nature and humanity have conditioned Western thought ever since.

Why are appeals to nature, indeterminate a concept though it may be, so effective? According to Hansen (2006: 813), appeals to "nature" can be rhetorically very powerful and persuasive, and are often made to overshadow or "naturalize" truth claims that are actually quite tenuous and political:

...invoking 'nature' serves to inoculate against criticism or further scrutiny and to invest partisan arguments and interests with moral or universal authority and legitimacy. Uses or constructions of 'nature' are inevitably and invariably 'ideological' in the sense that they serve ultimately the purpose, as all public discourse, of presenting particular views, understandings and interests as being 'for the common good', 'universal' and 'right'. Appeals to nature or to natural qualities are ... powerful because they invoke genuine, eternal and non-negotiable qualities.

\footnotetext{
${ }^{3}$ Note however, and following Heller (2007) that this characterization of GMOs as unnatural is far from universal. Heller shows how the Confederation Paysanne in France has established a successful anti-GMO campaign on the basis of a framing that sees GMOs as "uncultural", or at odds with France's traditional artisanal culinary culture.
} 
Hansen (2006) argues that in keeping with this semiotic fluidity, a number of different narratives of nature exist, including nature-as-pure, nature-as-threat, nature-as-challenge, nature-as-vulnerable and natureas-imperfect. While I argue that the framing of nature-as-pure is the most significant of these framings for antiGMO activism in the West (particularly in the 1990s and early 2000s), it is important to note that not all struggles against GMO agriculture have used this framing of nature to situate their criticism. As Kinchy (2012), Fitting (2006, 2011), and Gupta (2015) note, struggles in Latin America, among indigenous Hawaiians, and elsewhere have been driven by other narratives about nature, often in ways that do not dualistically separate nature from humanity instead framing nature as an ancestor ("Mother"). However, at least in Western Europe, North America and Australasia, a framing of nature as pure has been a significant normative driver of antiGMO activism. Within the nature-as-pure narrative, "nature" is presented as an inherently good, safe, secure, just and healthy place or state, powerfully contrasted with the bad, unknown, dangerous, unpredictable, and even immoral connotations of non-natural interference in nature (Hansen 2006). Moreover, nature is assumed to exist pre-discursively (Soper 1995), and thus few questions are asked as to what constitutes the boundary between the natural and non-natural. For Hansen (2006: 830)

...it is perhaps in this sense that the uses of 'nature', 'natural' and 'naturally' can be described as truly ideological, that is, they serve to perpetuate the notion of a common ... understanding about the distinction between nature/the natural and that which has been scientifically or otherwise altered or interfered with.

Not only is nature inherently pure and just; the "nature" of "nature" is assumed to be intuitive, self-evident and absolute, eternal and immutable (see also Braun 2009).

While of special importance to anti-GMO activism, natural purity discourses have long been foundational to Western environmentalism. As Sturgeon (2009: 13) has argued,

...dominant Western cultural myths have presented nature as a foundation of truth while at the same time imagining history as a story of the movement from nature to culture ... it is not accidental that the embodiment of nature as the source of truth, inspiration, and inevitability develops in some of the same historical and cultural contexts ... that see the rise of a particular form of environmentalism.

This discourse of nature has been pervasive in the conservationist movement, which has often seen nature as separate from humanity, and often more sacred and pure. Indeed, the wilderness ecology movement, dating back to the days of Sierra Club founder John Muir, has often mobilized images of nature-as-pure to generate public concern for urbanization and resource use, whilst calling for total preservation or "dehumanization" of landscapes, often in the face of indigenous land claims (Kosek 2005; Tsing 2005). As will be explored below, there are important connections between wilderness ecology and the nature-purity section of the anti-GMO movement. From this basic understanding of the rhetorical power that natural purity holds within the Western cultural imaginary, I examine how natural purity narratives have been used in GMO opposition movements, often employing them to engage with publics' insufficiently reflective assumptions about the world, a way of thinking that Gramsci (1972) termed "common sense."

\section{Writing technonatures}

Opposition to GMOs is manifest in a wide array of arenas: among environmental NGOs such as Greenpeace and Earth First!; among political parties ranging from green and social democratic parties to far more conservative ones such as the Austrian Freedom Party; among activist intellectuals like Vandana Shiva (1989) and Jeremy Rifkin (Howard and Rifkin 1977; Rifkin 1997), and within the mainstream media. While the bases for opposition are diverse and target economic, ecological, health, and ethical implications of the technologies (Cook et al. 2004), many actors have been animated by concerns that GMOs are unnatural: that they violate the sanctity or purity of nature or transgress non-negotiable natural boundaries and represent a 
reckoning with nature that is sure to have dire consequences. These discourses have been manifest in activist movements and electoral political campaigns. I will give examples of this tendency in both of these areas to show how the notion that GMOs transgress or trouble boundaries of what counts as "nature" formed a significant moral basis for opposition.

\section{Activist opposition}

As Levidow (2000: 326) argues, "in general, environmentalist movements have recast 'nature' as a realm of purity, morality and fragility." Various radical and mainstream activist groups have mobilized notions of the unnaturalness of GMOs to animate their resistance (Schurman and Munro 2009, 2010). For example, during the late 1990s, the GenetiX Snowball was launched as a direct action campaign in Britain (Wall 2000: 82). It involved "participants visiting a site where genetically modified crops ha[d] been planted" where they would "dig or pull up a number of plants, wrap them neatly in biohazard bags and then turn themselves over to the police." In 1999, another direct action campaign that involved the destruction of 150 GM trees owned by Zeneca Corporation took place in Britain. The anonymous perpetrators explained their actions, stating, "those who are manipulating the DNA of trees ... show contempt for our planet and the life it supports" (Wall 2000: 85). These two examples show how activists draw attention by mobilizing the idea that GMOs are unnatural. In the first instance, GMOs are compared to bio-hazardous or radioactive materials, contaminating the environment and requiring immediate and total removal. The second example of anti-GMO activism uses the language of "contempt" to refer to the actions of scientists and corporations involved in the production of GM trees. In this case, GMOs are seen to exemplify a disregard for the sacred laws of nature to which we are beholden.

Anti-GMO activists have often relied upon narratives that link GMOs with pollution, contamination, Frankenstein or monstrousness (Schurman and Munro 2009). We see the use of such metaphors in an activist campaign from New Zealand. The group Mothers Against Genetic Engineering (MAdGE) was formed in the early 2000s by New Zealand pop artist Alannah Currie, who had been painfully alerted to some of the potentially problematic consequences of modern industrial agriculture after her sister died from Creutzfeldt-Jakob disease (Weaver 2010). The group's activism - along with those of other environmental groups in New Zealand - was partially driven by concerns over the scheduled lifting of a moratorium on GE research by October of 2003. Through a variety of provocative campaigns, MAdGE sought to bring public awareness to the growing threat of GMO foods in the New Zealand food supply, particularly targeting mothers, who were said to be responsible for buying eighty percent of food consumed by New Zealand households (Weaver 2010). While MAdGE's edgy activist style drew much attention and helped foster a high degree of critical public awareness towards GMOs in New Zealand (several large supermarket chains made efforts to promote themselves as GM-free in the months following MAdGE's campaigns), MAdGE is also significant for the way that narratives of nature feature prominently in their activism.

In October 2003, MAdGE waged a campaign against research into cow's milk with transgenic human enzymes that could be fed to human infants (Bloomfield and Doolin 2011). Appearing on billboards in Auckland, their ads featured images of a four-breasted woman attached to an industrial milking machine with a GE branding on her thigh. Elsewhere MAdGE argued that "if women's essence, their milk, their means of nourishing their young is taken away from them, usurped and commodified, the damage to their life force is unimaginable" (MAdGE 2003). The group suggests that it would take "monstrous arrogance to even contemplate interfering with the material essence of womanhood." Here, women's "essence" as nurturers and baby-feeders is invoked to deride a "monstrous" transgression of the natural order, reinforcing coherent metaphors of GMOs as monstrous or Frankenfoods that disrupt an essential nature and an essential womanhood. They go on to state, "no commercially made formula has ever been able to replicate mother's milk. Doesn't that tell us something, not just about its complexity, but about its uniqueness, its perfect natural design?" Women's "essence" - materialized in their breast milk - is framed as a "perfect natural design", a gift from God or his secular alias Nature. If women's essence is perfect, pure, and sacred, then the creation of a chimeric transgenic milk product is the opposite: defiled and sacrilegious. Its very existence represents an affront to the order of Nature; an unwarranted boundary-crossing that disrupts the essential order of things. Between the monstrous corporeality of the cow-woman depicted in billboards and concerns over the "monstrous" interference in the essence of womanhood provided by transgenic milk, we can see how semiotic connections between appropriate 
bodies, appropriate gender roles and appropriate patterns of socio-natural interaction are made, with each emanating from the same essential natural order. Our intuitive understandings of what women are supposed to look like and supposed to do activate concerns for the self-evidently unnatural ways in which these natures are transgressed by the milk.

\section{Electoral political discourses}

Discourses of natural purity, cleanliness, pollution and contamination have also been used in electoral politics, with significant effects. While green political parties have generally opposed GMOs for many reasons, what is significant is that opposition to GMOs has extended into electoral politics far beyond the environmental left. As examples from Tasmania and Austria demonstrate, the resonance of anti-GMO politics with neoliberal governments and political parties of the far right highlights the dangers of this indeterminacy.

The Australian state of Tasmania has sought to develop a reputation as a niche producer of high-end produce for export nationally and overseas (ABC 2014). In achieving this end, the state has cultivated an image of "clean and green" (Cocklin 2008). Central to this imaginary is Tasmania's eschewal of GMOs. While Australia's federal state has been a proponent of GMOs (even opposing the Cartagena Protocol on Biosafety), and most states now grow GMO canola or cotton, Tasmania has remained stridently opposed to GMO agriculture, instituting a moratorium in 2001 that was extended indefinitely as of 2014. The links between Clean and Green and the GMO moratorium are not incidental. In fact, the cleanness and greenness of Tasmania - its ecological purity - is dependent on the perceived genetic purity of its crops. It cannot be clean (a synonym for pure) or green (a synonym for natural or in-sync with nature) if it is polluted or contaminated by transgenic crops. With Clean and Green Tasmania, we can see how genetic purity represents not only a safety standard or moral imperative, but also a shrewd marketing strategy for a small, relatively distant territory. In this instance, natural purity is invoked to give Tasmanian producers a leg up in international markets and domestically, particularly among consumers who seek to cultivate a "clean and green" self-image through their lifestyle choices. Rather than approaching GMO resistance from a concern over global equity and the pernicious effects of nature's commodification, Clean and Green Tasmania reproduces neoliberal rationality, or a competitive market-centric logic, as a calculated business strategy to boost consumer interest in their brand. The Clean and Green "brand" (and the Tasmanian government does call it a brand) gives Tasmanian produce a value-added boost, generating greater profits for Tasmanian agricultural businesses (Greens 2013). As public policy, opposition to GMOs has made economic sense for Tasmania, fully in keeping with neoliberal ideology. However, even on the right, the discourses of natural purity have been mobilized against GMOs towards various ends and not simply in accordance with calculative niche-market business rationality. This is well evinced with the politics of Austria's far-right Freedom Party (FPO).

Austria is among the most anti-GMO countries in the world. A full seventy-eight percent of Austrians feel that GMO food is "fundamentally unnatural" and that it makes them feel uneasy (EC 2010: 26). Austria once sought a blanket ban on GMOs, a policy that has been rejected by the EU (Lee 2008). While opposition to GMOs includes the green and social democratic parties Grune and SPO respectively, it has also taken root with the FPO. The FPO is notorious for being staunchly anti-immigrant, a policy approach that it assumed in the early 1990s at the same time as it experienced a substantial jump in opinion polls, from below ten percent to the high teens and low twenties. In its 288 page handbook (FPO 2013), FPO devotes a twenty page section to the problems with immigrants and asylum seekers, and the need for immigrants to return home, a policy called "minus-immigration", all the while claiming that "Austria is not a country of immigration" (FPO 2013: 30). Numerous anecdotes of non-Austrian people doing bad things coupled with daunting immigration statistics and foreboding references to Islamic fundamentalism pervade this section of the handbook. At the same time, the handbook devotes a large section to GMOs, which it categorically opposes as contaminating substances (p. 70). There can be no doubt that complicated political calculations and electoral pressures went into the formulation of the FPO's anti-GMO policy. The party's critique of GMOs cannot be dismissed as wholly driven by a concern with their "unnaturalness", and critiques of the potential health and environmental impacts of GMOs, as well as their implications for farmers' rights are included in the analysis as well. Nonetheless, it is clear that such a position is in no way incompatible with their other xenophobic policies. Moreover, and whether the FPO itself was driven by this or not, it is not difficult to see the semiotic connection here between transgenic 
crops that contaminate or pollute the purity of Austria's crops and soils and immigrant groups whose cultural or racial inappropriateness contaminates or pollutes the purity of Austrian soil or the Austrian "nation." Here, Haraway (1997: 60) reminds us, "transgenic border-crossing signifies serious challenges to the 'sanctity of life' for many members of Western cultures, which historically have been obsessed with racial purity, categories authorized by nature, and the well-defined self." Immigration, like GMOs, disrupts those well-defined notions of selfhood and nature.

\section{GMOs, matter out of place and hybrid natures}

How do we evaluate what is at stake in these activist campaigns? What accounts for the discursive purchase, or popular discursive resonance, they have generated? Part of what makes these metaphors so successful is their wider cultural resonance: in other words, the extent to which a certain discursive construct coheres with the values or worldview of a particular culture. Kwiecinski (2009) has observed that GMOs operate as a modern-day taboo. Taboos exist in every society, often to maintain boundaries between discrete, socially relevant objects or categories (Kwiecinski 2009). Though they often emerge for important social or sanitary reasons, they take on a life of their own. Others have sought to understand GMOs as hybrid natures, destabilizing the boundary between the natural and cultural (Braun 2004). One of the most salient ontological boundaries in Western society has been that between nature and culture (Plumwood 1993; Sturgeon 2009). As living creations of Western technoscience, GMOs disrupt the nature-culture dualism; they disrupt the sacredness of nature. By crossing this boundary, they become taboo. Within a worldview that separates culture and nature in hard-and-fast terms, the social disruption caused by hybrid natures that do not fit neatly into either category can lead to their rejection as inappropriate or even dangerous. In conceiving of GMOs as a modern-day taboo, we can understand the success of discourses that frame them as pollutants or contaminants. These discourses of pollution, contamination, and even monstrousness can all be understood as relating to Mary Douglas' conception of dirt as "matter out of place" (1966: 35). For Douglas, dirt and dirtiness are not inherent conditions; they represent the situational transgression of boundaries of appropriateness. Empty beer cans become pollution when they are left at the beach, but not when they are recycled. Pollution and contamination thus represent the violation of boundaries of purity, and the discursive purchase of these metaphors partially emanates from wider cultural concerns about unwarranted boundary crossings and violations of nature-culture dualisms. Thus with GMOs as with sexual or hygiene taboos, there is both an inherent distaste for the boundary violation and a fear of the consequences that it will bring.

References to contamination, pollution and Frankenstein have given discursive purchase to the idea that GMOs violate the sanctity of nature (Hammond 2004; Hansen 2006; Schurman and Munro 2009). Within this trope of natural sanctity, the purity of nature is seen to be fundamentally threatened by "contamination" from GMOs. It is within this narrative that the GenetiX Snowball campaign can be understood as constructing GMOs as contaminating, hazardous objects that are incompatible with nature. As Levidow (2000: 347) stresses, this discourse of pollution presents GMOs as not simply a health and safety threat, but as an inherent moral wrong, "irreducible to scientific measurement or management." Efforts to disrupt field trials or to "decontaminate" are therefore framed as morally just and legitimate: the restoration of a natural order. It is not hard to see how concerns over pollution or contamination correlate with wider cultural concerns with dirt and defilement (Douglas 1966). Indeed, precisely what makes GMOs "pollution" is the fact that they violate sacred boundaries between nature and culture; that they are seen as essentially different from their cisgenic relatives, despite nearidentical genetics.

Along with pollution discourses, Frankensteinian discourses also inspire concerns with 'matter out of place.' Frankenstein's creation was a monstrous, grotesque figure. The monster's very construction disrupted boundaries of appropriate conditions of human creation and human embodiment. His mere existence was an inherent wrong, a defilement of the laws of nature, to which his hideous appearance was testament. The bolt through his neck reinforces the inherent grotesqueness of a cyborg figure in the western cultural imaginary. Along with the Frankenfoods trope, we see this image reproduced with the cow-woman of MAdGE's campaign against GMO milk. She embodies the "monstrous" intervention of technoscience into the sacred, perfect domain of Nature (MAdGE 2003). Just like the bolt in Frankenstein's neck, the extra two breasts and the industrial milking machine attached to her signify matter out of place; transgressing the natural boundaries between 
essentially constituted objects of knowledge (Douglas 1966; Haraway 1991). In this way, the Frankenfood metaphor, as with pollution and contamination metaphors, stresses the inherent wrongs with such boundary crossings and violations of natural purity.

However, this inherent disgust with the border-violence caused by GMOs is not the only way purity discourses have emboldened concern for GMOs. For some, the impurity or unnaturalness of GMOs leads to concerns over potentially negative if not disastrous consequences of their use. In this case, it is not simply the fact that they are unnatural that causes concern, but the connection between unnaturalness and unintended or unknown consequences that generates public apprehension. Fears over nature "hitting back" are mobilized on this discursive terrain. Within this narrative, nature is often given a certain agency, and we are told that "nature will do this ... nature will react, nature will respond with vengeance..." (Hansen 2006: 826). In general, this signifies the concern that scientists and humans more widely will pay for interfering in the natural order of things. It is in this sense that we can understand some of the concerns that led to the precautionary approach of the Cartagena Protocol on Biosafety, as activists and some governments, including many from the Global South, made a convincing case that GMOs contained potential unknown risks that required use of the precautionary principle, thus formalizing an agreement that has granted states significant leeway in controlling the crossborder flow of GMOs (see Andree 2007; Carroll 2016). Moreover, the activist campaigns against Zeneca's GM trees that spoke of "contempt" for nature resonates within this discourse: by violating and undermining nature's authority and will, we will pay unforeseen consequences.

It is here that we can see a different use of metaphors of pollution, contamination, foreignness and monstrousness. For it is not simply the inherent defilement caused by pollution and contamination that makes it wrong; it is the implications of this that we fear. Pollution and dirt are not simply inherently repulsive; they are the harbingers of disease and destruction. Monsters are not simply scary because they are ugly but because they threaten us with bodily harm. Thus it is the unknowability of the consequences of violating natural purity that poses a set of concerns separate from those of the inherent immorality of genetic defilement.

Thus, we can see how in keeping with Douglas (1966), much of the cachet of these scripts comes from the way they resonate with wider cultural fears about pollution and contamination and specifically the transgression of nature-culture dualisms. Both the inherent wrongness of transgressing culturally significant boundaries and fear of the consequences of such border crossings animate opposition to GMOs as technologies that violate nature-culture dualisms, and threaten or undermine the purity of nature. Their hybridity destabilizes the stark division between the natural and the social as is made intelligible through dualistic ontologies. Within the context of Western ontologies deeply structured by nature-cultural dualisms, hybrid natures that disrupt those dualisms have thus incited a widespread uneasiness among the publics that activists have successfully mobilized. However, as the next section explores, from a social justice perspective, the consequences of such successful opposition have been contradictory and require careful scrutiny.

\section{Problems with nature purity}

Although they may have been strategically useful for mobilizing public awareness and concern over the surreptitious introduction of GM foods into the food system, nature purity discourses are problematic for two reasons. First, appeals to nature have been used to justify racist, sexist, heterosexist and colonial systems of oppression and domination, whilst underpinning common conservative justifications for material inequality (Sturgeon 2009). Instead of being part of the struggle for a more socially just world, the nature purity side of the anti-GMO campaign acts to further entrench nature-essentialism. Central to feminist, antiracist, queer and postcolonial struggles is the destabilization and problematization of truth claims rooted in nature (Soper 1995). This is because "nature" has been used as a justification for white, male and Western superiority. The ideas that women are "naturally" more emotional, weaker, or less intelligent than men; that colonized peoples are "closer to nature" and therefore less civilized than Westerners; that the sexuality of queer people is inherently "unnatural"; that it is "human nature" to be greedy and selfish; or that "natural selection" is what determines who is rich and who is poor have long been mobilized as justifications for systemic oppression. It is not only transgenic crops that are seen as monstrous, contaminating and polluting. We must ask which forms of human 
corporeality and self-expression come to be similarly framed and defamed when such discourses are presented and accepted as truth. ${ }^{4}$

This semantic link between eschewing GMOs' unnaturalness and the social implications of understanding certain human subjectivities as "unnatural" or "out of place" is no more obvious than in the policies of Austria's Freedom Party. Their overall policy approach to GMOs demonstrates concern over purity, contamination, dirt; and parallels their attitudes toward immigrants. Just as they eschew the violation of the genetic purity of their crops, they do not want the genetic purity of the Austrian nation to be contaminated with foreign blood and culture. It is not hard to see in such purity-based rejections of contaminant populations, whether transgenic crops or asylum seekers, the encroaching veil of eugenics. As Haraway (1997: 61) says, "the history and current politics of racial and immigration discourses in Europe and the United States ought to set off acute anxiety ... [We] cannot help but hear in the biotechnology debates the unintended tones of fear of the alien and suspicion of the mixed." If part of the project of radical emancipatory politics has been to deconstruct and dispel the notion that there is a "natural" order that is inherently "pure", "true" and "just", then invocations of the nature-as-pure narrative run counter to that project. They reinforce the notion that there is a nature that holds the essence of truth; that governs us and dictates the contours of morality to us, and that we must accept and obey. Rather than appealing to natural essentialisms as the MAdGE campaign does, we must critique, deconstruct and interrogate such claims to nature-as-truth.

Second, nature-as-pure narratives are problematic because they prevent us from seeing how the current manifestation of GMOs is a result of contingent and mutable political economic arrangements that are themselves necessarily violent but not necessary. Outright rejections of GMOs based on their "unnaturalness" force us into a dichotomy whereby we can either have GMOs governed within the framework of neoliberal capitalism, or we must get rid of them altogether. The potential for GMOs to be incorporated into an agri-food system that is socially just is precluded from the discussion, and the tenuous and contingent link between biotechnology and neoliberalism goes unchallenged. Concerns for the ethical implications of a world where market rationality and the profit motive dictate everything and nothing is left to "nature" are understandable (see Rifkin 1997). But this is a world of our current capitalist system given technological omnipotence and ethical free-reign, and not an intrinsic consequence of technoscience itself. Moreover, while the political economic implications of such a critique may be encouraging as a warning against the long-term consequences of biotechnological capitalism, the case of Tasmania's Clean and Green policy demonstrates that these discourses can just as easily be mobilized in the interests of capital and to the cause of neoliberalization. Tasmania uses the neoliberal cultural lexicon to achieve its brand status as clean and green. Without a deeper critique of the pernicious effects of GMO agriculture as it is currently constituted under capitalism, oppositional movements that lambast GMOs' violation of nature can just as likely be the basis of a new niche-market accumulation strategy for capital as an emancipatory resistance effort against it.

While these activist groups' and political parties' rhetoric mobilize nature-culture dualisms that constitute the natural and cultural worlds as ontologically distinct and oppositional, I want to emphasize that the use of these discourses and dualisms is not some clever ploy of activists to prey on the irrational fears of unsuspecting publics, but a reflection of deeply engrained cultural beliefs about nature and our relationship with(in) it. Rhetoric situated within a nature-culture dualistic framing is not the result of any deliberate attempt by activists to exploit the strategic expediency of those discourses, even if they may ultimately be of strategic benefit. Also, it is important to note that the extent to which groups' rhetoric adheres to the framing of natural purity discourse and extends nature-culture dualistic thinking is highly variable and contradictory. Just as culture and society cannot be separated from the so-called "natural" world, neither can dualistic framings and rhetoric be separated from the cultural context from which they emanate.

It is in this way that we can understand the use of nature purity narratives as a critique rooted in what Gramsci termed "common sense." Oppositional actors articulate their concerns through the cultural lexicon that

\footnotetext{
${ }^{4}$ This is not to say that activists who use nature-purity narratives in their rhetoric are in any way seeking to advance essentialist discourses that naturalize sexism, racism, heterosexism or colonialism. In most cases the opposite is true. However, the overall effect of rhetoric that positions nature as inherently good, immutable and outside of the social is likely to give further discursive purchase to the rhetoric of those seeking to use naturalizations to justify social oppression and injustice rather than encourage a critical rethink of such rhetoric.
} 
is immediately intelligible to them, in this case, the "unnaturalness" of GMOs. Because of the cultural pervasiveness of nature-culture dualisms, this line of criticism is intuitively resonant with publics, and reflects common sense understandings of the world that do not require a deeper reflexive analysis of structural dynamics to make sense. However, though these common sense framings are thus easily accessible to publics, they prevent us from understanding underlying conditions that may ultimately be more critically problematic. For this reason, Gramsci calls for the renovation of common sense into good sense, or a critical, reflexive understanding of the underlying and relational bases of injustice and oppression. With the case of GMOs, this might include a deconstructive approach to the idea that GMOs are "unnatural" coupled with a critical political economic analysis of the way GMOs are imbricated within neoliberal capitalist power relations and the pernicious social, political and ecological consequences that may bring. Yet this is not to say that each movement falls on one side of a good sense-common sense dualism. On the contrary, real world activism often combines common sense and good sense framings, both consciously and unconsciously. Still, there are clear examples of movements that have rooted their critiques in the tangible political-economic consequences of GMOs under neoliberalism and avoided eschewing GMOs as unnatural, indicating that the distinction between common sense approaches and good sense approaches deserves analytical consideration. I will now examine these good sense approaches to anti-GMO activism.

\section{Alternative discourses, alternative activisms}

Discourses of natural purity have thus had a profound effect in anchoring much of the anti-GMO movement, and are integral to our understanding of the cultural politics of GMOs. However, they have not been the only effective resistance strategy. As this section will show, activist campaigns that directly target the problematic political economic implications of GMOs as they are currently constituted within capitalism have also had notable, though modest successes. Two examples - Canadian farmers' resistance to Monsanto's Roundup Ready wheat and the global campaign to ban terminator technology - evince this nascent trend. Together, they speak of the potential for an alternative approach to anti-GMO activism that is cognizant of the contextually specific problems of GMOs, as they currently exist within neoliberal capitalism, demonstrating what Gramsci (1992) called 'good sense.'

\section{Roundup Ready wheat}

In Growing resistance: Canadian farmers and the politics of genetically modified wheat, Emily Eaton (2013), whose work I draw on heavily in this section, shows how Canadian farmers successfully fought against Roundup Ready (RR) wheat in a way that did not rely on appeals to natural purity, but rather challenged the specific problems with RR wheat and the undemocratic, neoliberal framework behind its planned introduction. While the campaign was launched in 2001, by 2004, Monsanto announced that it would be withdrawing its application for commercial release of RR wheat after years and billions of dollars' worth of work on the project. It was not concerns of natural purity or Frankenfoods that mobilized resistance to RR wheat, but rather a largely (but not exclusively) producer-led campaign that targeted the specific contextual problems of RR wheat. Various agricultural organizations from across the Prairie Provinces including the Canadian Wheat Board (CWB) united behind the idea that RR wheat was neither necessary nor beneficial for Canadian farmers and the Canadian wheat economy. They argued that agronomically, the herbicide-tolerance trait was not necessary to solve weed problems specific to wheat, but would conversely have negative ecological effects as the transgenes flowed horizontally to other plants, including weeds. In other words, the costs would likely outweigh the benefits, unlike with canola, which many of the same farmers had enthusiastically adopted. They also critiqued RR wheat on economic grounds: wheat is a staple crop in the prairies, and the high quality and nutritional value of Canadian wheat is valued on international markets, despite the relatively unproductive yields that prairie farmers garner. Given the high value ascribed to Canadian wheat and the opposition to GMOs in Europe and Japan, two of Canada's major export markets, the activists anticipated that RR wheat would tarnish the image of Canadian wheat and seriously endanger its export potential.

Politically, the opposition movement derided Monsanto's attempts to pursue the commercialization of RR wheat in a way that was unaccountable and undemocratic. Monsanto's refusal to disclose publically their field test results and the biotech industry's vehement opposition to GMO labeling solidified an image of power- 
hungry, unaccountable corporations increasingly gaining control over farmers' livelihoods. However, while discourses of democracy, accountability and collective decision-making animated the movement, lurking beneath the surface was a more forceful political economic critique. Ever since the late nineteenth century, Canadian wheat farmers had banded together in solidarity to fend off the advances of both capital and the state. Indeed, they played a key role in the development and success of the social democratic Canadian New Democratic Party (NDP), particularly in Saskatchewan, where the party formed the first social democratic government in Canada in 1944. Despite a wildly different context under neoliberalism in the early 2000s, Canadian prairie wheat farmers chose to frame their opposition to GMO wheat in a discourse of collective decision-making for the public good rather than supporting individual market rationality. Moreover, they quietly decried the political economic impacts RR would bear. Having perhaps learned from their experiences with GMO canola ${ }^{5}$, farmers saw RR wheat as a technology designed to generate maximal profits for Monsanto whilst exacerbating farmers' dependency on the corporation for seeds and pesticides. Indeed, in a declarative statement made by the CWB about RR wheat that was signed by farmers all over the world, the technology was framed "as a means for multinational seed companies to strip farmers of their capacity to reproduce seed outside of the market" (Eaton 2013: 144). In problematizing the ways markets and multinational corporations immobilize and disempower farmers, the statement squarely places its opposition in the context of political economic relations rather than with the technology itself. ${ }^{6}$

At the same time, it is important to recognize the limits to this particular movement. While concerns of equity, transparency and democracy were significant to the Canadian struggle against Roundup Ready wheat, they were likely of less significance in the United States, where farmers were also successful in convincing Monsanto to back down (see Schurman and Munro 2010). This suggests that although meaningful progress may have been made in emphasizing the importance of social justice concerns in Canada, what ultimately held the day was the economic irrationality of GMO wheat. Therefore, it is unclear whether discourses of democracy and equity could underscore successful resistance efforts to GMO crops that do make immediate economic sense for farmers. Thus, although laudable in many ways, the discursive terrain employed by the campaign against Roundup Ready wheat is vulnerable to the risk of being co-opted into a different common-sense framework: the profitable accumulation-oriented productivism of the GMO industry itself that has been rhetorically powerful in co-opting farmers into GMO agriculture in many parts of the world, what Newell (2009: 27) has termed "biohegemony."

Overall, we can see with Roundup Ready wheat the success of an opposition movement that is cognizant of the contextual political economic dynamics of its struggle. Rather than framing their opposition in natureessentialist terms, this movement located its opposition with the specific agronomic and economic problems posed by RR wheat for the Canadian wheat economy, and ultimately, to the livelihoods of farmers themselves. More importantly, it recognized the problems with a set of political-economic relations that were undemocratic and unaccountable, empowering corporations at the expense of farmers. Though often hidden, social justice concerns and even a criticism of neoliberal social relations were embedded within the critique. That these concerns animated a Northern struggle against GMOs is also significant, reminding us that corporate power, neoliberalization, and commodification are not only of concern in the global South, but in the North as well, where nature purity discourses have been most salient (Cronon 1995). This enables us to see that while concerns of the agronomic and economic impacts of any GMO variety are context-specific, the wider dynamics of neoliberal enclosure and farmers' disempowerment are endemic to GMO agriculture, at least under neoliberalism. These concerns are well voiced through another successful resistance struggle that also targeted the pernicious political economic impacts of GMO agriculture's power relations, though primarily in the global

\footnotetext{
${ }^{5}$ As Pechlaner (2012) recounts, GMO canola came to operate as a technology treadmill that farmers adopted hesitantly due to competitive market pressures and despite a sense of injustice.

${ }^{6}$ It is also likely that these farmers were successful because they framed their arguments in terms of agronomic and political economic costs and benefits, cohering with the dominant scientific rational discourse of both industry and policy-makers. On the other hand, while activists who employ natural purity narratives may enjoy popular resonance, their use of such discourses may exclude them from mainstream scientific legitimacy. In other words, both the approach taken by Saskatchewan farmers and the approach taken by groups such as MAdGE are rely on the mobilization of certain discursive terrains. However, while natural-purity discourses may resonate among general publics, they are also subject to discipline insofar as they clash with the scientific-rational discourse of industry and policy-makers.
} 
South, in the struggle against GURTs, or, as they were effectively labeled by Canadian NGO Rural Advancement Fund International (RAFI, now ETC Group), terminator technology.

\section{Terminator terminated}

The now infamous terminator technology (TT) was developed as a transgenic event by Delta and Pine Land, an American cottonseed breeder, in the mid-1990s. The technology's purported purpose is to render the seeds of each crop sterile, preventing the environmental release of second-generation crops, and ensuring greater controllability over transgenic plants in the environment. However, for opponents, TT also holds a darker promise, as it precludes farmers from saving seeds, thus ensuring their continual need to purchase new seeds each season. It thus has the potential to render farmers more subservient to seed breeders and biotech firms, whose intellectual property rights become biophysically enshrined in the seeds themselves. Critics argue that by deepening farmers' dependency and vulnerability, the technology offers to further entrench relations of inequality between the North and South and between farmers and agribusiness, further advancing the commodification of agriculture, and dismantling traditional, communal, and non-market practices of seedsaving. However, resistance to TT has been strident, successful, and driven by a forceful critique of the problematic socio-economic consequences of the technology for farmers. Within two years of the first patents for TT being issued, the global opposition movement had not only won a global moratorium on the technology but had also forced Monsanto (which had plans to acquire the technology from Delta and Pine) to distance itself from the technology and abandon plans for its commercialization (Srinavasan and Thirtle 2003). Spearheaded by groups in the Global North such as RAFI, the Spanish NGO GRAIN and by partner groups in the South, the global campaign against TT represents an important moment in the resistance movement against both GMO agriculture and neoliberalism more generally.

The first tangible political victory against TT came mere months after the patent was granted to Delta and Pine. In May 1998, members of the Convention on Biodiversity (CBD) met at the Fourth Conference of the Parties meeting (COP 4) in Bratislava, Slovakia. For the first time, countries discussed the nascent TT, concluding that further consideration of the technology would be required. When the Parties met again at COP 5 in 2000, they agreed on a moratorium on field-testing for TT (Oguamanam 2005). Significantly, and in contrast with the CBD's subsequently negotiated Biosafety Protocol, COP 5 made specific reference to "socioeconomic impacts" of the technology, citing these as a reasonable justification for proscribing commercial release (CBD 2000). In the meantime, governments in the North and South had instituted or pushed for their own moratoria, activist campaigns had further advanced their cause, and Monsanto had announced that it would not be pursuing commercial development of the technology despite a plan to buy patent-holding Delta and Pine. At least for the time being, the international community had resoundingly rejected TT.

How was the campaign against TT so successful, and what sort of political discourses did it mobilize in its efforts? The campaign against Terminator Technology started with activist work conducted by RAFI in 1998 (Scoones 2008). The group uncovered Delta and Pine's secret patent on TT and made it public through a campaign that coined the terminator metaphor. RAFI then partnered with international groups, particularly in India, waging a campaign against terminator technology, or "suicide seeds." RAFI produced regular press releases documenting and providing critical analysis on new developments with TT, maintaining pressure on delegates at the CBD meetings and elsewhere. It also issued a mass letter-writing campaign to US Agriculture Secretary Dan Glickman and to hundreds of other officials from around the world (RAFI 1998f). Finally, RAFI members participated in numerous public fora including the COP 4 meeting, where members spoke out against the technology (RAFI 1998c).

Central to RAFI's campaign was an emphasis on the political economic impacts of the technology. In its first ever report on terminator technology issued only weeks after Delta and Pine Land had secured a patent for the technology RAFI (1998a) argued that it "...threatens to eliminate the age-old right of farmers to save seed from their harvest and it jeopardizes the food security of 1.4 billion people ... who depend on farm-saved seed" (1). Later reports would argue that terminator technology was merely a mechanism for biotech firms to capture greater profits (1998c), that it would force farmers to rely on markets rather than communal practices for their livelihoods (1998e), and that even public breeders would be pressured by neoliberal administrative logic to adopt TT (1998b). 
RAFI (1998d) further critiqued the way intellectual property rights and patent laws undergirded the massive power shift away from peasant farmers and toward seed multinationals, thereby drawing attention to how terminator technology's imbrication with wider neoliberal institutions was at the heart of its pernicious political economic impacts for farmers. Finally, RAFI (1999) called upon a different role for the USDA, one that would be in the interests of the public rather than seed-breeding corporations. Ultimately, even with the 2000 global moratorium on field-testing agreed upon at COP 5, RAFI (2000) expressed disdain, decrying the CBD's inability to agree upon a total ban for TT despite some support for a total ban among Southern countries. Its continued and relentless pressure on CBD members likely played an important role in ensuring that the moratorium was extended indefinitely at the COP 8 meeting in 2006.

The success of the anti-terminator campaign by RAFI and other groups shows the potential for resistance efforts that stress the political economic impacts of technologies and the ways they are regulated. RAFI's approach consistently articulated how terminator technology would merely be a return to neo-colonial relations, as poor Southern farmers would be further disempowered and taken advantage of by large Northern corporations. It critiqued the marketization of social relations and showed how such marketization would necessarily have class-based effects that would further disempower those who were already poor. RAFI connected its critique of terminator technology with wider struggles over food sovereignty waged by groups such as La Via Campesina. Importantly, as with the campaign against Roundup Ready wheat, RAFI never resorted to direct critiques of terminator technology as "unnatural", or to blanket rejections of GMO agriculture. It focused squarely on terminator technology and the specific socio-economic impacts it would have.

Overall, as with the campaign against RR wheat, the anti-terminator campaign evinces the success of anti-GMO activism that is rooted in a deeper critique of neoliberalism and colonialism. Though far from the norm $^{7}$ and not without limits, the successes of these two struggles demonstrate the potential for activist struggles that directly target the socio-economic effects of a technology within a particular political economic regime, rather than simply the technology itself. In understanding what differentiates these campaigns from the naturepurity driven opposition discussed earlier, it is helpful to consider Gramsci's (1992) notion of good sense versus common sense. Gramsci saw common sense as the uncritical set of ideas through which an existing hegemonic ideology is reproduced in everyday life. In its simplistic commitment to nature-culture dualisms and disregard for questions of power and justice, nature purity discourses bespeak a common sense perspective on GMOs. In contrast to common sense, Gramsci saw good sense as the critical, subversive perspective reached through an immanent critique of existing hegemonic power relations (see Simon 1982). Good sense lays bare the unjust foundations of a hegemonic configuration and is thus a necessary starting point for any counter-hegemonic struggle. In this sense, the two oppositional campaigns discussed here represent good sense, and thus provide a necessary starting point for further counterhegemonic struggles, whether against the neoliberal GMO food economy, the commodification of nature, or capitalism more broadly.

However, we cannot detach the success of RAFI's campaign from the overarching context of natureessentialist opposition to GMOs. Despite its own avoidance of such overt rhetoric, RAFI benefited from the cultural resonance of nature-purity narratives. Moreover, RAFI mobilized powerful images of suicide seeds and terminators to advance its campaign, subtly evoking concerns over suicide as a violation of the natural right to life, or with the terminator's unnatural cyborg figure. However, while RAFI's coining of the "Terminator" metaphor may appear to be "anti-cyborg" (Haraway 1991), what is problematic about the Terminator is not only his cyborgness, but rather how he embodies American militarism, corporate technoscience, death and destruction. The metaphor thus encompasses critiques of imperialism, militarism and techno-capitalism whilst resonating with popular essentialist concerns over cyborg unnaturalness. In this context, we must ask whether there remains space for an approach to activism that can strategically channel the affective energies of essentialisms whilst remaining primarily driven by a critique of underlying political economic conditions. It is possible that in the short term, mobilizing scripts and tropes that resonate with popular natural narratives whilst firmly situating one's own analysis within a deeper critique of commodification holds potential for future activists that seek to oppose the commodification of nature, with GMOs or otherwise, as RAFI has done here. Finding a way to strategically mobilize common sense framings whilst ultimately destabilizing those framings

\footnotetext{
${ }^{7}$ I understand the norm of anti-GMO politics as being located in the nature purity-driven movements mentioned above.
} 
is a challenge, but one that may nonetheless bear fruit for future activist campaigns. Such a tactic is paradoxically reminiscent of what Gramsci called trasformismo, or the process through which resistance efforts are coopted within a hegemonic framework, transmogrified to support rather than subvert the normative basis for a hegemonic configuration. Perhaps what is called for then is a process of counter-trasformismo, as activist struggles strategically appropriate hegemonic framings, such as nature purity narratives, reshaping them into part of a wider counter-hegemonic critique and struggle against neoliberalism.

\section{Conclusion: rewriting technonatures}

This article has sought to orient understandings of the role played by discourses of nature in shaping the political and economic trajectories of GMO agriculture. It has demonstrated how the semiotic fluidity of nature has been mobilized differentially among a multiplicity of movements that share little beyond their rejection of GMOs as unnatural. It has shown how the position of those opposed to GMOs because they are "unnatural" is rooted in a discourse of natural purity that sees GMOs as a transgression of an inviolable boundary between the human and natural words and therefore inherently unjust or as dangerous pollutants likely to have unforeseeable negative consequences. I have sought to critically explore some of the implications of this narrative of natural purity. In valorizing the natural as a pre-discursive essence of truth, natural purity discourses do little to deconstruct the way naturalizations have been used to legitimize sexist, racist, heterosexist and colonial systems of injustice and oppression. Rather, in failing to interrogate the root causes of unjust and oppressive institutions and power relations, they may revitalize the discursive purchase of appeals to nature as a justification for the way things are.

Moreover, these discourses do little to challenge the critical, though contingent, reality of GMOs' location within the wider framework of neoliberal social relations. To this end, they not only leave unchecked the political economic and class consequences of GMOs are they are currently constituted, but preclude any role for biotechnology in a socially just future. As we have seen, this political indeterminacy makes natural purity discourses just as much an effective tool for far-right anti-immigrant groups or a clever business strategy for niche-market producers as for progressive opponents of agricultural biotechnology. However, though in the minority, the success of resistance efforts to RR wheat in Canada and to terminator technology around the world show that deeper political economic critiques of GMOs as imbricated within processes of neoliberal enclosure and commodification can also be effective.

This article has explored the cultural origins of natural purity narratives, how they operate in GMO discourse, why they have been so culturally resonant and thus effective, and why they nonetheless remain politically problematic. It has also shown that alternative strategies are both possible and necessary, but that they may yet benefit from strategic appropriations of common sense discourses whilst retaining a firm grounding in structural critique. It is these good sense alternatives that hold the seeds to a socially just future world that may or may not contain GMOs. Future research in political ecology should further consider how GMOs and other "nature-cultures" may serve as sites for the contestation of not only how humans interface with the rest of nature but also of how power relations are negotiated within human societies.

\section{References}

ABC News. 2014. Tasmania's ban on genetically modified crops made indefinite in bid to protect clean, green brand. 10 January 2014.

Andree, P. 2007. Genetically modified diplomacy: the global politics of agricultural biotechnology and the environment. Vancouver: UBC Press.

Benford, R. and D. Snow. 2000. Framing processes and social movements: An overview and assessment. Annual Review of Sociology, 26: 611-639.

Bloomfield, B. and B. Doolin. 2011. Imagination and technoscientific innovations: governance of transgenic cows in New Zealand. Social Studies of Science 41: 59-83.

Braun, B. 2009. Nature. In N. Castree, D. Demeritt, D. Liverman and B. Rhoads (eds.) A companion to environmental geography. Chichester: Wiley-Blackwell. Pp. 19-36. 
Braun, B. 2004. The intemperate rainforest: nature, culture and power on Canada's west coast. Minneapolis: University of Minnesota Press.

Carroll, M. 2017. The sticky materiality of neo-liberal neonatures: GMOs and the agrarian question. New Political Economy 22(2): 203-218.

Carroll, M. 2016. The new agrarian double movement: hegemony and resistance in the GMO food economy. Review of International Political Economy 23(1): 1-28.

Carroll, M. 2014. Biohegemony, interrupted: the limits to GMO agriculture in a neoliberal era. MA Thesis. Victoria, BC: University of Victoria.

Castree, N. 2005. Nature. London: Routledge.

Center for Food Safety [CFFS]. 2013. International labeling laws.

Cerny, P. 1996. Globalization and other stories: The search for a new paradigm for international relations. International Journal 51: 617-637.

Cocklin, C. 2008. Competitiveness versus 'clean and green'? The regulation and governance of GMOs in Australia and the UK. Geoforum 39: 161-173.

Convention on Biological Diversity [CBD]. 2000. COP 5 Decision V/5. Retrieved from http://www.cbd.int/decision/cop/default.shtml?id=7147

Cook, G., E. Pieri and P. Robbins. 2004. 'The scientists think and the public feels': expert perceptions of the discourse of GM food. Discourse and Society 15: 433-449.

Cooper, M. 2008. Life as surplus: biotechnology and capitalism in the neoliberal era. Seattle: University of Washington Press.

Cronon, W. 1995. The trouble with wilderness: or, getting back to the wrong nature. In W. Cronon (ed.) Uncommon ground: Toward reinventing nature. New York: Norton \& Co. Pp. 69-90.

Douglas, M. 1984 [1966]. Purity and danger: an analysis of the concepts of pollution and taboo. London: Ark Paperbacks.

Eaton, E. 2013. Growing resistance: Canadian farmers and the politics of genetically modified wheat. Winnipeg: University of Manitoba Press.

Ekers, M. and A. Loftus. 2013. Revitalizing the production of nature thesis: A Gramscian turn? Progress in Human Geography 37(2): 234-252.

European Commission [EC]. 2010. Biotechnology report. Eurobarometer 73.1. Brussels: TNS Opinion \& Social.

Fitting, E. 2011. The struggle for maize: campesinos, workers, and transgenic corn in the Mexican countryside. Durham, NC: Duke University Press.

Fitting, E. 2006. The political uses of culture: maize production and the GM corn debates in Mexico. FocaalEuropean Journal of Anthropology 48: 17-34.

FPO Bildungsinstitut [FPO]. 2013. Handbuch freiheitlicher politick [Handbook of liberal politics]. Vienna: FPO Bildungsinstitut.

Gramsci, A. 1992. Prison notebooks. J. A. Buttigieg (ed.), J. A. Buttigieg and A. Callari (trans.). New York: Columbia Press. online

Greens, The. 2013. Tasmania 2030: a vision for a green, dynamic and prosperous Tasmanian economy. Retrieved from greenvision2030.com

Gupta, C. 2015. Return to freedom: Anti-GMO Aloha 'Aina activism on Molokai as an expression of placebased food sovereignty. Globalizations 12(4): 529-544.

Hammond, K. 2004. Monsters of modernity: Frankenstein and modern environmentalism. Cultural Geographies 11(2): 181-198.

Hansen, A. 2006. Tampering with nature: 'Nature' and the 'natural' in media coverage of genetics and biotechnology. Media, Culture \& Society 28(6): 811-834.

Haraway, D. 1997. Modest_Witness@Second_Millenium.FemaleMan®@_Meets_OncoMouse: feminism and technoscience. London: Routledge. 
Haraway, D. 1991. Simians, cyborgs and women: the reinvention of nature. New York: Routledge.

Heller, C. 2007. Techne versus technoscience: divergent (and ambiguous) notions of food "quality" in the French debate over GM crops. American Anthropologist 109(4): 603-615.

Heller, C. 1999. Ecology of everyday life: rethinking the desire for nature. Montreal: Black Rose Books.

Herring, R. 2008. Opposition to transgenic technologies: ideology, interests and collective action frames. Focus on Global Challenges 9: 458-463.

Hoban, T. 2004. Public attitudes towards agricultural biotechnology. ESA Working Paper, No. 04-09. Agricultural and Development Economics Division of the Food and Agriculture Organization (FAO).

Hughes, E. 2005. The contaminated risk of GM crops: Nationalism and the genetic modification debate. Journal of Public Affairs 5:251-262.

James, C. 2016. ISAAA Brief 52-2016: executive summary. International Service for the Acquisition of Agribiotech Applications. Retrieved from http://www.isaaa.org/resources/publications/briefs/52/executivesummary/default.asp

Kinchy, A. 2012. Seeds, science, and struggle: the global politics of transgenic crops. Cambridge, MA: MIT Press.

Kwiecinski, J. 2009. Genetically modified abominations? EMBO Reports, 10(11): 1187-1190.

Lee, M. 2008. EU regulation of GMOs: law and decision making for a new technology. Cheltenham: Edward Elgar.

Levidow, L. 2000. Pollution metaphors in the UK biotechnology controversy. Science as Culture 9: 325-351.

Mothers Against Genetic Engineering in Food and the Environment [MAdGE]. 2003. Why not just genetically engineer women for milk? 1 October 2003. Retrieved from www.scoop.co.nz/stories/P00310/S00003.htm

Marris, C. 2001. Public views on GMOs: deconstructing the myths. EMBO Reports 2(7): 545-548.

Marris, C., B. Wynne, P. Simmons and S. Weldon. 2001. Public perceptions of agricultural biotechnologies in Europe. Final Report of the PABE Research Project. Commission of European Communities. Retrieved from http://csec.lancs.ac.uk/archive/pabe/docs/pabe_finalreport.pdf

McCauley, D. 2015. Protest, politics and produce: a resource account of anti-genetically modified organism activism. Local Environment 20(1): 34-49. preprint

Mielby, H., P. Sandoe and J. Lassen. 2013. Multiple aspects of unnaturalness: are cisgenic crops perceived as being more natural and more acceptable than transgenic crops? Agricultural and Human Values 30: 471480.

Newell, P. 2009. Bio-hegemony: the political economy of agricultural biotechnology in Argentina. Journal of Latin American Studies 41(1): 27-57.

Oguamanam, C. 2005. Genetic Use Restriction (or Terminator) Technologies (GURTs) in agricultural biotechnology: the limits of technological alternatives to intellectual property. Canadian Journal of Law and Technology 4: 59-76.

Ong, A. 2006. Neoliberalism as exception: mutations in citizenship and sovereignty. Durham: Duke University Press.

Pechlaner, G. 2012. Corporate crops: biotechnology, agriculture, and the struggle for control. Austin, TX: University of Texas Press.

Pigeon, L-E. and L. Letourneau. 2014. The leading Canadian NGOs' discourse on fish farming: from ecocentric institutions to biocentric solutions. Journal of Agricultural and Environmental Ethics 27: 767-785.

Plumwood, V. 1993. Feminism and the mastery of nature. London: Routledge.

Purdue, D. 2000. Anti-GenetiX: the emergence of the anti-GMO movement. Aldershot: Ashgate.

Rajan, S. (Ed.) 2012. Lively capital: biotechnologies, ethics, and governance in global markets. Durham: Duke University Press.

Rifkin, J. 1998. The biotech century: how genetic commerce will change the world. London: Phoenix.

Robbins, P. 2012. Political ecology: a critical introduction. Second Edition. Chichester, UK: Wiley. 
Rural Advancement Foundation International [RAFI]. 1998a. The terminator technology. March/April 1998. Retrieved from http://www.etcgroup.org/sites/www.etcgroup.org/files/publication/416/01/raficom59terminator.pdf

Rural Advancement Foundation International [RAFI]. 1998b. Terminating food security. May 15 1998. From http://www.etcgroup.org/content/terminating-food-security

Rural Advancement Foundation International [RAFI]. 1998c. RAFI takes terminator to COP IV in Bratislava... and COP IV responds. May 30 1998. Retrieved from http://www.etcgroup.org/content/rafi-takesterminator-cop-iv-bratislava-and-cop-iv-responds

Rural Advancement Foundation International [RAFI]. 1998d. Terminator trends. June 30 1998. Retrieved from http://www.etcgroup.org/sites/www.etcgroup.org/files/publication/429/01/occ_vol5no1_1998_termtrn d.pdf

Rural Advancement Foundation International [RAFI]. 1998e. World's largest international agricultural research network vows not to use terminator technology. October 23 1998. Retrieved from http://www.etcgroup.org/sites/www.etcgroup.org/files/publication/394/01/news_cgiaravoids.pdf

Rural Advancement Foundation International [RAFI]. 1998f. Monsanto's 'spectre' dims. November 121998. Retrieved from http://www.etcgroup.org/sites/www.etcgroup.org/files/publication/389/01/rafigenospectre98.pdf

Rural Advancement Foundation International [RAFI]. 1999. USDA must abandon terminator technology. October 29 1999. Retrieved from http://www.etcgroup.org/sites/www.etcgroup.org/files/publication/358/01/nrudsaterm99.pdf

Rural Advancement Foundation International [RAFI]. 2000. COP 5 cops out. June 16 2000. Retrieved from http://www.etcgroup.org/sites/www.etcgroup.org/files/publication/320/01/news_despite.pdf

Schurman, R. 2004. Fighting "Frankenfoods": industry opportunity structures and the efficacy of the antibiotech movement in Western Europe. Social Problems 51: 243-268.

Schurman, R. and W. Munro. 2010. Fighting for the future of food: activists versus agribusiness in the struggle over biotechnology. Minneapolis: University of Minnesota Press.

Schurman, R. and W. Munro. 2009. Targeting capital: a cultural economy approach to understanding the efficacy of two anti-genetic engineering movements. American Journal of Sociology 115(1): 155-202.

Scoones, I. 2008. Mobilizing against GM crops in India, South Africa and Brazil. Journal of Agrarian Change, 8(2/3): 315-344.

Shaw, A. 2002. "It just goes against the grain." Public understandings of genetically modified (GM) food in the UK. Public Understanding of Science 11: 273-291.

Shiva, V. 1989. Staying alive: women, ecology, and development. London: Zed Books.

Simon, R. 1982. Gramsci's political thought: an introduction. London: Lawrence and Wishart.

Soper, K. 1995. Feminism and ecology: realism and rhetoric in the discourses of nature. Science, Technology and Human Values 20(3): 311-331.

Smith, N. 1991. Uneven development: nature, capital, and the production of space. Cambridge, MA: Blackwell.

Sturgeon, N. 2009. Environmentalism in popular culture: gender, race, sexuality and the politics of the natural. Tucson: University of Arizona Press.

Swyngedouw, E. 1999. Modernity and hybridity: nature, regeneracionismo and the production of Spanish waterscape. Annals of the Association of American Geographers 89: 443-465.

Tsing, A. 2005. Friction: an ethnography of global connection. Princeton, NJ: Princeton University Press.

Wall, D. 2000. Snowballs, elves and skimmingtons? Genealogies of environmental direction action. In B. Steel, M. Paterson and B. Doherty (eds.) Direct action and British environmentalism. London: Routledge. Pp. 59-92.

Williams, R. 1983. Keywords: a vocabulary of culture and society. London: Fontana Press. 